\title{
Sophie Ménard, Les Fantômes nuptiaux chez Zola
}

\section{Damiano Sinfonico}

\section{(2) OpenEdition}

\section{Journals}

\section{Edizione digitale}

URL: http://journals.openedition.org/studifrancesi/5728

DOI: $10.4000 /$ studifrancesi.5728

ISSN: 2421-5856

\section{Editore}

Rosenberg \& Sellier

\section{Edizione cartacea}

Data di pubblicazione: 1 septembre 2011

Paginazione: 448

ISSN: 0039-2944

\section{Notizia bibliografica digitale}

Damiano Sinfonico, «Sophie Ménard, Les Fantômes nuptiaux chez Zola», Studi Francesi [Online], 164 (LV | II) | 2011, online dal 30 novembre 2015, consultato il 13 janvier 2021. URL: http://

journals.openedition.org/studifrancesi/5728 ; DOI: https://doi.org/10.4000/studifrancesi.5728

Questo documento è stato generato automaticamente il 13 janvier 2021.

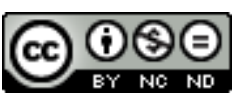

Studi Francesi è distribuita con Licenza Creative Commons Attribuzione - Non commerciale - Non opere derivate 4.0 Internazionale. 


\title{
Sophie Ménard, Les Fantômes nuptiaux chez Zola
}

\author{
Damiano Sinfonico
}

\section{NOTIZIA}

SOPHIE MÉNARD, Les Fantômes nuptiaux chez Zola, in «Romantisme», n. 149, 2010, 3e trimestre, pp. 97-110.

1 Che gli spettri facciano capolino nel mondo di Zola, suscita più stupore nel lettore che spavento nei personaggi. Benché non si tratti di vere presenze fantasmatiche, rappresentano l'inquietante epifania di un mondo di ombre che viene a disturbare, più che il sonno dei vivi, le notti degli amanti. L'A. legge questi residui di romanzo d'appendice come l'alchemica capacità dello scrittore di materializzare nella loro irrealtà certe credenze mediche e folcloristiche: non tanto vittoria del romanzesco sulla scienza, quanto metafora di un'allucinazione e di una superstizione comune. Trattenute sulla soglia, queste ombre introducono un luogo di soglia anche tra il corpo degli amanti, sui quali grava una tacita interdizione: schiacciati tra un lutto non pienamente compiuto e una fecondità negata in Le Rêve, tra l'omicidio e l'interposizione dell'antico marito tra i due amanti in Thérèse Raquin. Se la sterilità è, nel primo caso, un rito continuo in cui si perpetua la prima notte di nozze, l'intoccabilità diventa nel secondo caso una litote della sessualità, il suo assurdo rovesciamento nell'estraneità dei due corpi. In prossimità della morte, dunque, lo spettro vampirizza e intrappola nella sua maledizione anche il corpo degli amanti. 